\title{
Correspondence
}

\section{Moralising judgements}

SIR

I was alarmed by Dr Simon Lundy's description of his consultation with a psychologically disturbed young man in whom he considered testing for HIV antibodies (vol 15: 92-93). Phrases such as 'shifty young man', 'probably homosexual', 'HIV negative, he says', 'we only had his word to go on that he had had a previous negative result', and 'he did not seem to be the most reliable of witnesses' set the tone of this remarkable doctor-patient encounter. Dr Lundy's impulse to perform an HIV test seemed to have less to do with optimum care of his patient than with his own prejudice. However, he offers no counselling and actually refrains from asking the man's consent in case he is refused. Then after barely listening to his history, and making the briefest examination of his mental state, Dr Lundy despatches him with a 'major tranquilliser in hefty doses'. Is he suggesting that all homosexual men (if indeed this patient was homosexual) with a psychological presentation are to be assumed to have HIV disease of the brain until proved otherwise? He would do well to read the excellent article in the same issue by Dr Michael Ross who exhorted us to refrain from moralising judgements about HIV infection.

MICHAEL KING MD PhD MRCP MRCGP MRCPsych Senior Lecturer and Honorary Consultant Academic Department of Psychiatry University of London The Royal Free Hospital Pond Street London NW3 $2 Q G$

\section{Response to moralising judgements}

SIR

I am surprised and sorry to have caused Dr King alarm; he has perhaps not understood that my article was a description of my 'inner consultation', where the ethical issues were considered: it was not a case study.

I think that I have honestly described some of my observations, thought processes and internal debate during this consultation. The suggestions that he makes about my beliefs and intentions bear no relation to the article. His interpretations I must gently rebut.

I wonder if his letter is prompted more by a desire to be 'in print' on this issue than to make a contribution to the ethical debate on consent to tests and treatment?

DR S LUNDY

Thamesmead Medical Associates Gallions Reach Health Centre London SE28 8BE 